Aquaculture

September 2016, Volume 462, Pages 47-55

http://dx.doi.org/10.1016/j.aquaculture.2016.04.030

http://archimer.ifremer.fr/doc/00332/44361/

(c) 2016 Elsevier B.V. All rights reserved

\title{
Influence of water temperature on the economic value of growth rate in fish farming: The case of sea bass (Dicentrarchus labrax) cage farming in the Mediterranean
}

\author{
Besson $\mathrm{M}^{1,2,{ }^{*} \text {, Vandeputte Marc }}{ }^{2,3,4}$, Van Arendonk Jam ${ }^{1}$, Aubin $\mathrm{J}^{5}$, De Boer $\operatorname{ljm}^{6}$, Quillet $\mathrm{E}^{2}$, \\ Komen $\mathrm{H}^{1}$
}

\footnotetext{
${ }^{1}$ Animal Breeding and Genomics Centre, Wageningen University, PO Box 338, 6700 AH Wageningen, The Netherlands

${ }^{2}$ Génétique animale et biologie intégrative, INRA, AgroParisTech, Université Paris-Saclay, 78350 Jouyen-Josas, France

${ }^{3}$ IFREMER, Chemin de Maguelone, 34250 Palavas-les-Flots, France

${ }^{4}$ INRA, Agrocampus, France

${ }^{5}$ Ouest Rennes, UMR1069 Sol Agronomie Spatialisation, 65 rue de Saint Brieuc, 35042 Rennes, France

${ }^{6}$ Animal Production Systems Group, Wageningen University, PO Box 338, 6700 AH, The Netherlands

*Corresponding author : Mathieu Besson, email address : mathieu.besson@wur.nl
}

\begin{abstract}
:
In sea cage farming, fish are exposed to seasonal variations of water temperature, and these variations can differ from one location to another. A small increase in water temperature does not only stimulate growth of the fish (until an optimal level) but also lowers dissolved oxygen concentration in water. Dissolved oxygen may then become a rearing constraint during the production cycle if the oxygen requirement of fish is higher than the supply. The impact of this constraint on production parameters (stocking density of cages and/or batch rotation) and thus on economic profit of a farm will depend on both local thermal regime and growth potential of the fish. Increased growth is one of the most important traits in a breeding objective to increase production capacity and profitability. We used a bioeconomic model of seabass reared in cages to calculate the economic value (EV) of increasing thermal growth coefficient (TGC) by selection in different conditions of average temperature (Tm) and amplitude of temperature variation (Ta). Tm and Ta values were taken from different locations in the eastern and western Mediterranean. Results show that increasing TGC has two consequences: (i) fast growing fish reach harvest weight earlier, which increases the number of batches that can be produced per year, and (ii) fast growing fish have higher daily feed intake and, consequently, higher daily oxygen consumption. To balance the oxygen demand and availability in a cage, a farmer might have to reduce the average stocking density, resulting in fewer fish produced per batch. Consequently, EV of TGC is positive when $\mathrm{Tm}$ is $19.5{ }^{\circ} \mathrm{C}$ or $21^{\circ} \mathrm{C}$, when an increase in number of batches produced compensates for the decrease in stocking density. EV of TGC is negative or null in areas where $\mathrm{Tm}$ is closer to $18{ }^{\circ} \mathrm{C}$ because the increase in number of batches produced cannot compensate for the decrease in stocking density. Our results show, for the first time, the importance of variation in ambient temperatures for breeding programs in fish. Statement of relevance The economic impact of improving growth rate in sea
\end{abstract}


cage farming system depends on temperature. This result is important for the development of breeding objectives maximizing economic return in fish breeding programs.

\section{Statement of relevance}

The economic impact of improving growth rate in sea cage farming system depends on temperature. This result is important for the development of breeding objectives maximizing economic return in fish breeding programs.

\section{Highlights}

- First study to calculate the economic value of growth rate in different temperature conditions in the Mediterranean When the average temperature is $18^{\circ} \mathrm{C}$, the economic impact of growth rate is null. - When the average temperature is $19.5^{\circ} \mathrm{C}$ or $21^{\circ} \mathrm{C}$, the economic impact of growth rate is positive. First study to show the importance of variation in ambient seawater temperatures for breeding programs in fish

Keywords : Economic values, Bioeconomic model, Fish farming, Genetic improvement, Temperature, Thermal growth coefficient 


\section{Introduction}

Genetic improvement aims at modifying the performances of animals and, in case of production limitations, can affect the management strategy of a farm. In dairy farming, for instance, increasing milk yield in a situation with milk quota decreases the number of milking cows on farms (Groen, 1989). Such changes in the production system need to be accounted for when building breeding objectives, guaranteeing that expected gains will be met (Groen, 1989; Amer et al., 1994). According to this principle, Rose et al. (2015) calculated the economic values of several traits, including live weight at different live stages, for sheep farms across different environments that varied in the amount and distribution of annual pasture growth. Pasture growth is a key parameter because it determines how much feed is available for sheep farms. The economic values of live weights were higher in regions with high and low variation, compared to regions with medium variation in pasture growth. This result was explained by changes in energy requirements when live weight was increased, which required different management adaptations according to the region. The conclusion was that breeding objectives for live weights could be similar for regions with either high and low variation of pasture growth but should be different for regions with medium variation of pasture growth. Such results demonstrate that breeding objectives should be finely tuned to the local conditions of production, according to constraints on input availability, namely, pasture growth and feed availability.

In fish farming, the potential economic impact of selective breeding for growth has been studied by Besson et al. (2014) in a recirculating aquaculture system where production of African catfish (Clarias gariepinus) is alternatively constrained by two limiting factors, either 
the nitrogen treatment capacity of the bio-filter, or the density of fish. However, such recirculating system differs from most fish culture systems by the fact that the environment (temperature and water quality) are highly controlled and stable. In most open production systems, such as sea cages, fish are exposed to seasonal variation in water temperature, and these variations can differ from one location to another. Temperature has a major impact on farm management and productivity for two main reasons. Firstly, fish are poikilothermic animals, implying that their metabolic activity and growth depend on ambient water temperature. Secondly, changes in water temperature generate variation in oxygen supply because warmer water can hold less dissolved oxygen which is vital for fish growth (Thetmeyer et al., 1999; Pichavant et al., 2001).

Therefore, we decided to investigate a sea cage system producing sea bass (Dicentrarchus labrax) in the Mediterranean where temperature conditions differ across regions. For instance, the average temperature in south Turkey is about $21{ }^{\circ} \mathrm{C}$, with an difference of $10.6{ }^{\circ} \mathrm{C}$ between winter and summer. In northwestern Italy, the average temperature is $18{ }^{\circ} \mathrm{C}$ and the difference is $9.5{ }^{\circ} \mathrm{C}$ (Llorente and Luna, 2013). For sea bass, growth is optimal around $24{ }^{\circ} \mathrm{C}$ (Person-Le Ruyet et al., 2004). Consequently, the time required to reach harvest weight, and therefore, costs associated with fish farming vary across regions (Gasca-Leyva et al., 2002). Llorente and Luna (2013) showed that the difference in water temperature between areas in the Mediterranean Sea is a major source of competitive advantages for fish farms. A higher annual average temperature generates faster growth and enables farmers to either produce more batches, or alternatively, bigger fish in a given production system. A lower seasonal difference is associated with less extreme summer and winter temperatures, closer to the optimum, resulting in better feed conversion ratio (Llorente and Luna, 2013). Moreover, the oxygen supply is potentially lower in south eastern Turkey than in eastern Spain (for the same level of water renewal). For sea bass, an oxygen concentration under $3.5 \mathrm{mg} / \mathrm{L}$ affects growth 
and causes mortality (Coves et al., 1991; Thetmeyer et al., 1999; Breitburg, 2002). Dissolved oxygen, therefore, may become a rearing constraint during the production cycle when the oxygen requirement of fish is higher than oxygen supply.

In fish farming, rearing constraints were shown to affect the economic impact of selective breeding for growth because the management strategy must be adapted to fit the change in fish performances (Besson et al., 2014). In case of sea cage farming, increasing growth will change the oxygen requirement at both individual and cage level which would imply changes in stocking management. Similarly to pasture growth in sheep farming, temperature conditions might affect the economic value of traits differently according to the location, with potential implications on the definition of breeding objectives. To our knowledge, the impact of temperature profiles on the economic impact of genetic improvement in cage farming has never been studied.

We investigated the economic impact of selection for growth rate in sea bass cages exposed to variations of water temperature inducing limitation on oxygen supply, using a bioeconomic modelling approach. Growth rate is considered the most important trait by fish farmers (SaeLim et al., 2012) and is consistently part of the breeding objectives. The bioeconomic model developed for recirculating aquaculture systems by Besson et al. (2014) was adapted to a sea cage system. By modelling the whole farm, we enable quantification of economic impacts from changes in management, such as stocking density, due to genetic improvement.

\section{Materials and methods}

\subsection{Bioeconomic model in the reference scenario}

The bioeconomic model developed in R ( $\mathrm{R}$ Development Core Team, 2008) is based on the model presented by Besson et al. (2014) to calculate economic values of growth rate and feed 
conversion ratio in a recirculating aquaculture system. The reference scenario of the model describes a hypothetical sea cage farm producing 1,000 tonnes of sea bass in southern France. The farm was composed of 34 circular cages of $600 \mathrm{~m}^{3}$ for pre-growing and 34 circular cages of $1,800 \mathrm{~m}^{3}$ for on-growing. Fish were stocked in pre-growing cages at $10 \mathrm{~g}$ and the fish were sold at a fixed harvest weight of $400 \mathrm{~g}$. Stocking took place all year round. The hypothetical farm and the bioeconomic model were based on information provided by Gloria Maris and Kefalonia Fisheries. The symbols used for different parameters of the bioeconomic model are summarized in Table 4.

\subsubsection{Physical parameters of sea water}

The daily temperature $T_{n}$ is modeled using a sinusoidal function with a period of 365 days (Fig. 1). As suggested by Seginer and Halachmi (2008), $\mathrm{T}_{\mathrm{n}}$ is given by:

$$
\mathrm{T}_{\mathrm{n}}=\mathrm{Tm}-\mathrm{Ta} \times \sin \left(2 \pi \frac{\mathrm{n}+\phi_{\mathrm{T}}}{365}\right)
$$

$\mathrm{n}=$ day $(1$ to 365$)$

$\mathrm{Tm}=$ mean water temperature $=18{ }^{\circ} \mathrm{C}$ in the reference scenario

$\mathrm{Ta}=$ amplitude of the variation $=5.77{ }^{\circ} \mathrm{C}$ in the reference scenario (corresponding to $\mathrm{a}$ difference of $2 \times 5.77=11.54{ }^{\circ} \mathrm{C}$ between the maximum and minimum daily value across the whole year)

$\phi \mathrm{T}=$ phase shift (time-delay) $=27.36$ days

In total, we tested 15 different scenarios of temperature profile according to three values of Tm and five values of Ta (Table 1). Several combinations of Tm and Ta are similar to real conditions in different regions of the Mediterranean Sea presented by Llorente and Luna (2013). The highest amplitude is displayed in eastern Spain where the difference between maximum and minimum temperature is $12.2{ }^{\circ} \mathrm{C}$. The lowest amplitude is observed in 
northwestern Italy and southern Greece where the difference between maximum and minimum temperature is $9.5^{\circ} \mathrm{C}$.

Dissolved oxygen concentration at day $\mathrm{n}$ in surface water $\left(\left[\mathrm{O}_{2}\right]_{\mathrm{n}}\right.$ in $\left.\mathrm{mg} / \mathrm{L}\right)$ is calculated from Weiss equation (Weiss, 1970) as a function of salinity (S, set to $39 \%$ ) and water temperature $\left(\mathrm{T}_{\mathrm{n}}\right.$ in ${ }^{\circ}$ kelvin $=\mathrm{T}_{\mathrm{n}}$ in $\left.{ }^{\circ} \mathrm{C}+272.15\right)$ :

$$
\begin{aligned}
{\left[\mathrm{O}_{2}\right]_{\mathrm{n}}=1.4722 } & \times \exp \left[-173.492+\frac{24963.39}{\mathrm{~T}_{\mathrm{n}}}+143.3483\right. \\
& \times \ln \left(\frac{\mathrm{T}_{\mathrm{n}}}{100}\right)-0.218492 \mathrm{~T}_{\mathrm{n}}+\mathrm{S} \times(-0.033096 \\
& \left.\left.+0.00014259 \mathrm{~T}_{\mathrm{n}}-0.00000017 \mathrm{~T}_{\mathrm{n}}^{2}\right)\right]
\end{aligned}
$$

The Weiss equation indicates that with higher the temperature there is lower oxygen concentration, as shown in Fig. 1.

\subsubsection{Fish model}

The fish model describes the daily weight and the daily weight gain of fish based on thermal growth coefficient (TGC). The two main model assumptions are: (i) growth rate is allometrically related to body weight (W in $\mathrm{g}$ ) and (ii) growth rate is an allometric constant related to mean daily water temperature averaged over the rearing period. However, the relationship between growth rate and water temperature is non-linear (see e.g. Person-Le Ruyet et al. (2004)). Therefore, the TGC formula needs to be corrected for the concave relationship between growth rate and temperature, which can be done by using a corrected temperature K as proposed by Mallet et al. (1999):

$$
\mathrm{TGC}=\frac{\mathrm{W}_{\mathrm{H}}^{1-\mathrm{b}}-\mathrm{W}_{\mathrm{I}}^{1-\mathrm{b}}}{\sum_{\mathrm{i}=1}^{\mathrm{n}} \mathrm{K}_{\mathrm{i}}} \times 1000
$$

$$
\begin{aligned}
& \mathrm{W}_{\mathrm{H}}=\text { harvest weight }=400 \mathrm{~g} \\
& \mathrm{~W}_{\mathrm{I}}=\text { initial weight }=10 \mathrm{~g} \\
& 1-\mathrm{b}=0.51
\end{aligned}
$$


TGC $=2.25$, so that harvest weight is achieved in 573 days on average in the reference scenario. TGC and 1-b were obtained through optimization to fit the calculated growth curve to the growth curve observed from farm data (personal communication).

$\mathrm{K}_{\mathrm{n}}=$ corrected temperature index

$$
\mathrm{K}_{\mathrm{n}}=\frac{\mathrm{T}_{\mathrm{opt}}\left(\mathrm{T}_{\mathrm{n}}-\mathrm{T}_{\min }\right)\left(\mathrm{T}_{\mathrm{n}}-\mathrm{T}_{\text {max }}\right)}{\left(\mathrm{T}_{\mathrm{n}}-\mathrm{T}_{\min }\right)\left(\mathrm{T}_{\mathrm{n}}-\mathrm{T}_{\max }\right)-\left(\mathrm{T}_{\mathrm{n}}-\mathrm{T}_{\mathrm{opt}}\right)^{2}}
$$

when $T_{\min } \leq K_{n} \leq T_{\max }$ and $K_{n}=0$ for other values.

$\mathrm{T}_{\min }=$ minimal temperature below which there is no growth

$\mathrm{T}_{\mathrm{opt}}=$ optimal temperature for which growth is maximal

$\mathrm{T}_{\max }=$ maximal temperature above which there is no growth

For sea bass, $\mathrm{T}_{\min }, \mathrm{T}_{\mathrm{opt}}$ and $\mathrm{T}_{\max }$ are respectively $12^{\circ} \mathrm{C}(\mathrm{K}=0), 24^{\circ} \mathrm{C}(\mathrm{K}=24)$ and $30^{\circ} \mathrm{C}(\mathrm{K}=$ 0) extrapolating from Person-Le Ruyet et al. (2004) and unpublished data. Therefore, $T_{n}$ must be between $12^{\circ} \mathrm{C}$ and $30^{\circ} \mathrm{C}$ to have a positive $\mathrm{K}_{\mathrm{n}}$ and hence a positive growth rate (Fig. 2). The daily weight $\left(\mathrm{W}_{\mathrm{n}}\right)$ and the daily weight gain $\left(\mathrm{DWG}_{\mathrm{n}}\right)$ were calculated as:

$$
\begin{gathered}
W_{n}=\left[W_{I}^{0.51}+\left(\frac{T G C}{1000} \times \sum_{i=1}^{n} K_{i}\right)\right]^{1 / 0.51} \\
D W G_{n}=W_{n}-W_{n-1}
\end{gathered}
$$

Feed conversion ratio (FCR) was modelled by combining a third order polynomial model from Person-Le Ruyet et al. (2004) that models feed efficiency as a function of temperature at a fixed body weight with an exponential model from Lanari et al. (2002) that models the variation of FCR with fish body weight. The resulting model was the following:

$$
\begin{aligned}
& \text { FCR }_{W n} \\
& =\alpha \\
& \times \frac{\mathrm{W}_{\mathrm{n}}^{0.14} / 1000}{1.318-\left(0.103 \times \mathrm{T}_{\mathrm{n}}\right)+\left(0.007174 \times \mathrm{T}_{\mathrm{n}}^{2}\right)-\left(0.0001395 \times \mathrm{T}_{\mathrm{n}}^{3}\right)}
\end{aligned}
$$


$\alpha$ is a scaling factor which was set to 2.6 to obtain a realized FCR of 2.0 in the reference scenario. Daily feed intake $\left(\mathrm{DFI}_{\mathrm{n}}\right)$ is calculated back from $\mathrm{FCR}_{\mathrm{n}}$ and $\mathrm{DWG}_{\mathrm{n}}$ by:

$$
\mathrm{DFI}_{\mathrm{n}}=\mathrm{DWG}_{\mathrm{n}} \times \mathrm{FCR}_{\mathrm{Wn}}
$$

Oxygen consumption was estimated via indirect calorimetry principles. Oxygen consumption per fish was calculated from the nutrient catabolized (nutrient digested minus nutrient retained corrected for branchial and urinary losses), using the oxy-caloric coefficient (Qox) of nutrient.

$$
\begin{aligned}
\mathrm{O}_{2-} \text { cons_fish }_{\mathrm{n}} & =\left[\left(\mathrm{DFI}_{\mathrm{n}} \times \mathrm{P}_{\text {feed }} \times \mathrm{D}_{\mathrm{P}}\right)-\left(\mathrm{DWG}_{\mathrm{n}} \times \mathrm{P}_{\text {fish }}\right)\right] \times \frac{\mathrm{E}_{\mathrm{P}}}{\mathrm{Q}_{\mathrm{ox}_{\mathrm{P}}}} \\
& +\left[\left(\mathrm{DFI}_{\mathrm{n}} \times \mathrm{F}_{\text {feed }} \times \mathrm{D}_{\mathrm{P}}\right)-\left(\mathrm{DWG}_{\mathrm{n}} \times \mathrm{F}_{\text {fish }}\right)\right] \times \frac{E_{\mathrm{F}}}{\mathrm{Q}_{\mathrm{ox}_{\mathrm{F}}}} \\
& +\left[\left(\mathrm{DFI}_{\mathrm{n}} \times \mathrm{C}_{\text {feed }} \times \mathrm{D}_{\mathrm{C}}\right)\right] \times \frac{\mathrm{E}_{\mathrm{C}}}{\mathrm{Q}_{\mathrm{ox}_{\mathrm{C}}}}
\end{aligned}
$$

$\mathrm{P}_{\text {feed }}, \mathrm{F}_{\text {feed }}, \mathrm{C}_{\text {feed }}=$ Protein, fat and carbohydrates content of the feed

$\mathrm{P}_{\text {fish }}, \mathrm{F}_{\text {fish }}=$ Protein and fat content of the fish

$\mathrm{D}_{\mathrm{P}}, \mathrm{D}_{\mathrm{F}}, \mathrm{D}_{\mathrm{C}}=$ Digestibility of protein, fat and carbohydrates

$\mathrm{Q}_{\mathrm{oxP}}, \mathrm{Q}_{\mathrm{oxF}}, \mathrm{Q}_{\mathrm{oxC}}=\mathrm{Oxy}$-caloric coefficient of protein, fat and carbohydrates

$\mathrm{E}_{\mathrm{P}}, \mathrm{E}_{\mathrm{F}}, \mathrm{E}_{\mathrm{C}}=$ Energy content of protein, fat and carbohydrates

All values of parameters in Eq. [9] are given in Table 2. The assumption in this equation is that fat deposition cannot be higher than the fat content of the feed. The value given by Eq. [9] are in line with values estimated by the Fishit-3 program $\left(r^{2}=0.993\right)$ (Kaushik, pers. comm, based on Cho, 1992; Cho and Kaushik, 1990; Kaushik, 1998).

The overall mortality is fixed at $10 \%$ from stocking to harvest. Thus, the cumulative mortality at a given day is expressed by a linear equation:

$$
\mathrm{M}_{\mathrm{Wn}}=0.00025 \times \mathrm{W}_{\mathrm{n}}-0.0025
$$




\subsubsection{Batch model}

A batch represents all the fish of the same cohort stocked in the same cage. A batch is first stocked at $10 \mathrm{~g}$ in a cage of $600 \mathrm{~m}^{3}$ (period 1), then the fish are transferred to a cage of 1,800 $\mathrm{m}^{3}$ (period 2). The transfer takes place when the rearing density reached $10 \mathrm{~kg} / \mathrm{m}^{3}$ in the 600 $\mathrm{m}^{3}$ cage. The number of $10 \mathrm{~g}$ fish stocked per batch was constrained by the daily oxygen supply in cages during the whole rearing period. Daily oxygen supply $\left(\mathrm{O}_{2} \_\right.$supply_cage $\left.{ }_{n}\right)$ depends on: 1) The concentration of dissolved oxygen in the cage which was constrained to a minimum $3.5 \mathrm{mg} / \mathrm{L}$. 2) The water flow going through the cage and carrying the oxygen. 3) The concentration of dissolved oxygen in water entering the cage. Daily oxygen supply at the cage level is expressed, therefore, as:

$$
\mathrm{O}_{2 \_} \text {supply_cage }_{\mathrm{n}}=\mathrm{WF}_{\text {min }} \times \mathrm{V}_{\text {cage }} \times\left(\left[\mathrm{O}_{2}\right]_{\mathrm{n}}-3.5\right)
$$

$\mathrm{WF}_{\min }=$ minimum water flow per $\mathrm{m}^{3}$. It was estimated to be $54 \mathrm{~m}^{3} / \mathrm{m}^{3} /$ day using data from the reference farms and constrained by oxygen supply.

$\left[\mathrm{O}_{2}\right]_{\mathrm{n}}=$ concentration of dissolved oxygen in water at day $\mathrm{n}$ from Eq. [2]

O2_supply_cage $e_{n}$ is variable according to water temperature at day $\mathrm{n}$ but $\mathrm{WF}_{\min }$ was $\mathrm{kept}$ constant. Water current depends, however, on coastal geography or weather conditions but we considered that all farms in all environments were undergoing the same water flow in order to allow fair comparison.

Combining Eq. [11] and Eq. [9], we estimated the maximum number of fish that could be sustained in the cage at day $\mathrm{n}\left(\mathrm{Nb} \_\right.$fish_max $\left.\mathrm{m}_{\mathrm{n}}\right)$ :

$$
\mathrm{Nb} f i s h \_m a x_{\mathrm{n}}=\frac{\mathrm{O}_{2 \_} \text {supply_cage }}{\mathrm{O}_{2 \_} \text {cons_fish }_{\mathrm{n}}}
$$

The number of fish stocked to reach $\mathrm{Nb}_{-}$fish_max $\mathrm{m}_{\mathrm{n}}$ at day $\mathrm{n}$ includes the cumulated mortality from day 0 to day $n$ :

$$
\text { Nb_fish_stocked }_{n}=\text { Nb_fish_max }_{n} /\left(1-M_{W n}\right)
$$


However, the number of fish stocked in a batch must be capped to avoid the oxygen demand to exceed the supply at any day $\mathrm{n}$ of the growth period. Then, the number of fish stocked is determined by the minimum value of $\mathrm{Nb}_{-}$fish_stocked $\mathrm{n}_{\mathrm{n}}$ over the whole growth period of the batch.

Consequently, the number of fish stocked or in other words the stocking density depends on the combination of oxygen supply and its consumption. During the production cycle, the oxygen consumption of the batch will always be lower than the supply except at one day, Dlimit, where oxygen consumption equals oxygen supply (Fig. 3). When the oxygen supply is low (in summer), a batch of smaller fish with a lower consumption of oxygen per fish, can contain more fish than a batch with bigger fish having higher oxygen requirements per fish. Therefore, the number of fish stocked depends on the date when the batch was stocked.

Finally, the production of fish per batch is given by:

$$
\text { Prod_fish } \text { batch }_{2}=\mathrm{Nb}_{-} \text {fish }_{0} \times \mathrm{W}_{\mathrm{H}}
$$

$\mathrm{W}_{\mathrm{H}}=$ harvest weight

\subsubsection{Farm model}

Fish production and feed consumption per batch are multiplied by the number of batches produced during a year to estimate the yearly fish production and feed consumption of the farm. In this study, we investigated a production system where fish are stocked all year round. To do so, we first calculated the production and feed consumption of a batch stocked at any

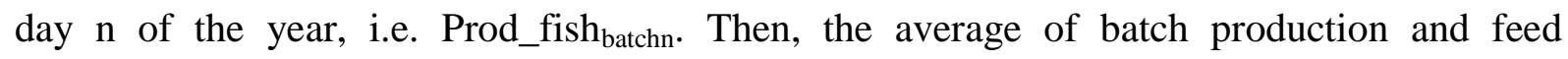
consumption is multiplied by the number of batches produced per year $\left(\mathrm{Nb} \_\right.$batch $\left.{ }_{\text {year }}\right)$ to obtain the average estimated farm production, independent on any specific stocking date, $\operatorname{Prod} \_f i s h_{\text {farm. }}$

$$
\text { Prod_fish }_{\text {farm }}=\frac{\sum_{\mathrm{n}=1}^{365} \text { Prod_fish }_{\text {batch }}}{365} \times \text { Nb_batch }_{\text {year }}
$$


The number of batches that can be produced per year $\left(\mathrm{Nb}_{-}\right.$batch $\left.\mathrm{year}\right)$ depends on the length of the production period and on the number of cages. In our study, the number of batches is constrained by the on-growing period because the length of this period $\left(\mathrm{L}_{\mathrm{P} 2}\right)$ is always longer than the pre-growing period. Note that the length of pre-growing and on-growing period depends on the stocking date of the fish (Fig. 3). The number of cages for on-growing,

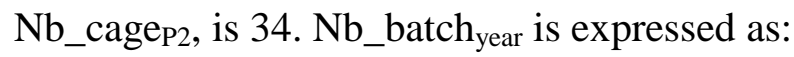

$$
\mathrm{Nb}_{-} \text {batch }_{\text {year }}=\mathrm{Nb}_{-} \text {cage }_{\mathrm{P} 2} \times \frac{365}{\mathrm{~L}_{\mathrm{P} 2}}
$$

Calculating the average production per cage across all possible stocking dates is a way to estimate potential production of a farm per year considering an indeterminate period of time. In the bioeconomic model, $\mathrm{Nb} \_$fish_stocked ${ }_{\mathrm{n}}$ was different across stocking dates in order to maximize cage production and to comply with lower oxygen supply in summer. For instance, when $\mathrm{Tm}=18^{\circ} \mathrm{C}, \mathrm{Ta}=5.77^{\circ} \mathrm{C}$ and $\mathrm{TGC}=2.25$, the average calculated stocking density was 91,022 fish per cage with a maximum of $121,908\left(16^{\text {th }}\right.$ of September $)$ and a minimum of 82,280 on the $\left(13^{\text {th }}\right.$ of December $)$.

In this study, every time a batch is harvested, a new one is stocked. When TGC increases, more batches can be stocked because $\mathrm{L}_{\mathrm{Pn}}$ decreases. Finally farm profit is given by:

$$
\begin{aligned}
& \text { Profit_farm }=\left(\text { Pfish } \times \text { Prod_fish }_{\text {farm }}\right)-\left(\text { Cjuv } \times \text { Juv_stocked }_{\text {farm }}\right) \\
& -(\text { Cfeed } \times \text { Feed_consumption } \text { farm })-\text { Cfixed }
\end{aligned}
$$

Pfish $=$ selling price of $1 \mathrm{~kg}$ of sea bass

Cjuv $=$ cost of juveniles

Cfeed $=$ cost of feed

Cfixed $=$ fixed cost

Juv_stocked $d_{\text {farm }}=$ number of juveniles stocked per year per farm

Feed_consumption farm $=\mathrm{kg}$ of feed distributed per year per farm 
All economic parameters are given in Table 3. Fixed costs are not detailed because the economic values represent the relative change in profit after genetic improvement. Therefore, the economic value depends on the costs that vary with genetic improvement. If the fixed costs are the same after genetic improvement, which is our case, they can be ignored in the calculation of economic values.

\subsection{Genetic change and economic value of growth rate}

The economic value of growth rate was calculated for 15 different temperature profile scenarios using the bioeconomic model in three steps:

1) The model was run for the current population mean for TGC $(\mu=2.25)$ to obtain the initial reference annual profit per farm, which was divided by annual fish production to obtain profit per kg of fish (Profit_fish ${ }_{\mu}$ ).

2) The model was run a second time when TGC mean value was increased by one genetic standard deviation $(\mu+\sigma g)$ to calculate the annual profit per farm after selection. From Vandeputte et al. (2014), $\sigma \mathrm{g}$ was estimated to be 0.13 . The annual profit per farm was divided by the reference annual fish production (i.e. before genetic improvement for TGC) according to Groen (1989) to obtain profit per kg of fish: Profit_fish $\mu+\sigma g$.

3) Finally, the economic value per genetic standard deviation was calculated for TGC as :

$$
\mathrm{EV}_{\mathrm{TGC}}=\text { profit_fish }_{\mu+\sigma \mathrm{g}}-\text { profit_fish }_{\mu}
$$

\section{Results}

\subsection{Effect of temperature profile on farm profit}

\subsubsection{Effect of average temperature Tm}

Increasing $\mathrm{Tm}$ from 18 to $21{ }^{\circ} \mathrm{C}$ decreased the time to reach harvest weight because the optimal temperature for sea bass growth is $24{ }^{\circ} \mathrm{C}$. The first consequence of this was that more 
batches could be stocked per year (Table 5). Furthermore, the longer the time to reach harvest weight, the higher the probability for the fish to undergo two summer periods. In summer, high temperature generates high growth hence high oxygen consumption, together with limited oxygen supply. Therefore, these periods are the most constraining regarding stocking density. When a batch went through two summers, the day when oxygen consumption of the batch equaled oxygen supply (Dlimit) occurred during the second summer when the fish reached harvest weight. Therefore, individual oxygen consumption was high at Dlimit, which in turn, strongly constrained the initial stocking density (Fig. 3a). Conversely, when a batch went through only one summer, Dlimit could occur earlier in the life of the fish, with smaller fish having lower oxygen needs, and then a potential to stock more fish (Fig. 3b). When Tm increased, growth rate was higher and more batches were in the second situation, with just one summer during the on-growing period. However, when Tm is higher, oxygen supply is lower. We observed that at Dlimit, the reduction in individual oxygen consumption results in a total oxygen demand that equals the lower oxygen supply. This results in similar stocking densities across a range of $\mathrm{Tm}$ values. In summary, increasing $\mathrm{Tm}$ only increased the number of batches produced (but not the number of fish per batch), which resulted in higher farm profit (Table 6).

\subsubsection{Effect of the amplitude of temperature $T a$}

Profit increased when Ta decreased (lower amplitude) for two reasons:

1) A lower amplitude reduces the periods where fish are exposed to extreme (higher or lower than $24{ }^{\circ} \mathrm{C}$ ) temperature conditions at which growth is reduced. With low Ta harvest weight was reached faster and more batches could be stocked in a year (Table 5).

2) Oxygen supply varies across the year. When the temperature was high (in summer) the oxygen supply was low (Fig. 1). Therefore, the stocking density of a batch is dependent on the period of low oxygen availability during summer. With low Ta the maximum temperature 
reached in summer was lower and the oxygen supply was, therefore, higher and thus more fish could be stocked per batch (Table 5).

\subsection{Economic value of thermal growth coefficient (TGC)}

Improving growth rate allowed reaching harvest weight in a shorter period of time and had two major impacts: 1) improving growth rate increased the daily feed intake and consequently, the daily consumption of oxygen as well (Eq. 9). When oxygen consumption increases, the farmers must stock less fish in a batch to avoid oxygen consumption to exceed the supply; 2) more batches can be produced. Improving growth rate decreased production per batch but increased the number of batches per year.

Variation of $E V_{T G C}$ as a function of $T a$ - When $\mathrm{Tm}$ was low $\left(18{ }^{\circ} \mathrm{C}\right)$ and $\mathrm{Ta}$ was high $(\geq 5.3$ ${ }^{\circ} \mathrm{C}$ ), the reduction in production per batch was not compensated by the higher number of batches, and improving growth rate thus decreased profit (Fig. 4). Consequently, the economic value of TGC (EV $\mathrm{EGC}_{\text {T }}$ ) was negative, $-0.01 € / \mathrm{kg}$ (Table 7). However, when Ta decreased (less fluctuation), the profit from improving TGC became null or even slightly positive, $\mathrm{EV}_{\mathrm{TGC}}=0.01$ when $\mathrm{Ta}$ is $4.75{ }^{\circ} \mathrm{C}$. This can be observed also when $\mathrm{Tm}$ is $19.5{ }^{\circ} \mathrm{C}$, when the $\mathrm{EV}_{\mathrm{TGC}}$ increases with Ta. When $\mathrm{Tm}$ was $21{ }^{\circ} \mathrm{C}$, however, the $\mathrm{EV}_{\mathrm{TGC}}$ started to decrease when Ta was lower than $5.3{ }^{\circ} \mathrm{C}$ because the oxygen available at Dlimit started to decrease, constraining the number of fish stocked per batch.

Variation of $E V_{T G C}$ as a function of $T m$ - When Tm was higher $\left(19.5{ }^{\circ} \mathrm{C}\right.$ or $\left.21{ }^{\circ} \mathrm{C}\right)$, the decrease in time to reach harvest weight due to improvement of TGC was higher than at 18 ${ }^{\circ} \mathrm{C}$. As an example, for $\mathrm{Ta}=6.09{ }^{\circ} \mathrm{C}$, this decrease was $2.87 \%$ at $\mathrm{Tm}=21{ }^{\circ} \mathrm{C}$ compared to $2.54 \%$ at $\mathrm{Tm}=18{ }^{\circ} \mathrm{C}$. We already saw in section 3.1.1 that a reduction in the time to reach harvest weight decreased the average oxygen consumption at Dlimit. Therefore, the decrease in number of fish stocked due to higher daily oxygen requirements was lower at $\mathrm{Tm}=21{ }^{\circ} \mathrm{C}$ 
than at $\mathrm{Tm}=18{ }^{\circ} \mathrm{C}$, and this reduction was compensated by the higher batch number at $21{ }^{\circ} \mathrm{C}$, while that was not the case at $18{ }^{\circ} \mathrm{C}$. Improving growth rate when $\mathrm{Tm}$ was $19.5{ }^{\circ} \mathrm{C}$ or $21{ }^{\circ} \mathrm{C}$ increased profit (Fig. 4) and hence the economic value of TGC (Table 7).

\section{Discussion}

The bioeconomic model developed by Besson et al. (2014) was adapted to investigate the economic impact of genetic improvement of sea bass produced in a sea cage farming system. In sea cages, fish are exposed to variations in water temperature, which has two consequences: variation in metabolic rate and feed intake (see Eq. 5) and variation in oxygen supply across the year (see Eq. 2 and Eq. 11). An increase in water temperature, increases the oxygen demand, because of an increase in feed intake, but decreases the oxygen supply. As a result, dissolved oxygen may become a rearing constraint during the production cycle when the oxygen requirement of the fish is higher than the supply. The aim of the study, therefore, was to estimate the economic impact of improving TGC of sea bass produced in sea cages in different scenarios of temperature profiles typically observed in the Mediterranean Sea. The differences in temperature profiles led to differences in oxygen supply profiles likely to modify the economic benefit expected from selective breeding for growth. This economic impact was expressed via economic values $(\mathrm{EV})$ calculated as extra profit obtained per $\mathrm{kg}$ of fish produced when increasing TGC by one genetic standard deviation. The definition of the $\mathrm{EV}$ of a trait is the economic gain /loss due to a change in a trait while keeping the other traits constant. Therefore, when calculating $\mathrm{EV}_{\mathrm{TGC}}$ we should not change other traits to avoid interactions effects that could bias our economic values. This is why we kept the total FCR constant while changing the TGC level.

Improving TGC leads to faster growing fish with higher daily energy requirement and therefore, higher daily oxygen consumption. Faster growth of fish has two consequences for 
farm management: 1) it forces farmers to reduce the average stocking density in order to avoid oxygen shortage, and 2) it accelerates the time period required to reach the targeted harvest weight, enabling farmers to produce more batches in a given time. We found that the economic value of TGC varied across tested scenarios differing in temperature profiles. In the range of averages and amplitudes tested, the economic value of TGC was influenced mostly by the average temperature. Accordingly, the Mediterranean can be divided in two regions: (i) the western part of the Mediterranean with an average temperature of $18{ }^{\circ} \mathrm{C}$, broadly encompassing the eastern coast of Spain, southern France and northwestern Italy. In this region, the economic value of TGC was close to zero or even negative (when $\mathrm{Ta}>4.9{ }^{\circ} \mathrm{C}$ ) because the higher batch rotation due to faster growth did not compensate for the reduction in stocking density, and (ii) the eastern part of the Mediterranean where the average temperature is $19{ }^{\circ} \mathrm{C}-21{ }^{\circ} \mathrm{C}$, encompassing western Greece, southern Greece and southern Turkey. Under these latter conditions, the economic value of TGC was positive. The difference with western Mediterranean is due to the fact that increasing average temperature limited the reduction of stocking density due to faster growing fish. Therefore, improving TGC increased profit because the increase in batch number compensated for the lower stocking density, resulting in a positive economic value.

Our results provide a first insight into the economic impact of genetic improvement of TGC of sea bass produced in sea cages under different temperature conditions. Our findings are supported by our previous study focused on recirculating aquaculture system (RAS) where we showed that the economic value of TGC was null when the limiting factor is the treatment capacity of the bio filter because increasing TGC increases daily feed intake and daily nitrogen emission (Besson et al., 2014). As a result, genetic improvement of TGC forces farmers to stock less fish to comply with the nitrogen treatment capacity of the bio-filter but this loss is compensated for by higher number of batches grown. Similarly, in a sea cage 
system limited with an average temperature of $18{ }^{\circ} \mathrm{C}$, the gain of productivity due to faster growing fish is offset by a lower stocking density due to higher oxygen requirements. The results of the present study and the results of Besson et al. (2014) show that it is essential to calculate the economic value of TGC in the right context with the right limiting factor to evaluate the economic impact of genetic improvement and to make decisions regarding breeding objectives.

In the present study, we considered that economic and technical parameters were fixed across the different temperature profiles. In reality, farms differ in their fixed and variable cost structure, which would impact the economic value of TGC. Those costs are, indeed, fixed until a certain limit. We could easily imagine that if the production doubles, farmers would need to hire technicians. However, we assume that the changes in fish production due to genetic improvement of TGC by one genetic standard deviation, in our case, will not impact fixed costs. Moreover, each farm has a different stocking strategy, depending on temperature profile. Some farms avoid stocking juveniles in winter when temperature is close to the minimal for sea bass $\left(12^{\circ} \mathrm{C}\right)$, because growth and feed efficiency are low. Water flow can also affect the profitability of the farm. The effects of water flow and average water temperature are similar with respect to oxygen supply. With a lower water flow, a lower amount of oxygen is supplied to the cage similarly as when average temperature Tm increases. Consequently, when water flow is lower, the number of fish stocked decreases and annual profit decreases as well. Water flow therefore acts as a scaling factor for profit. Keeping economic and technical parameters fixed enabled us to fairly compare the economic impact of genetic improvement for growth across temperature profiles considering an average farm producing sea bass in the Mediterranean. However, our model does not represent all the situations, and conclusions should be refined according to specific situations. 
From a theoretical point of view, the calculation of economic values is only relevant in a system with optimized management (Dekkers, 1991; Amer et al., 1994). This study used a management strategy where farmers optimized the number of fish stocked per batch across the year depending on the predicted temperature to prevent any drop of oxygen below the limit during production cycle. This study used a management strategy where farmers optimized the number of fish stocked per batch across the year depending on the predicted temperature to prevent any drop of oxygen below the limit during the production cycle. The relevance of this strategy is supported by studies from Seginer and Halachmi (2008) and Villanueva et al. (2013) who showed, using modelling, that stocking density varies from batch to batch according to environmental variation, i.e. rearing temperature. However, some farmers might decide to stock at the same safe density across the year to avoid a drop of oxygen below the safe limit. Such a management decision leads to an underutilisation of the system's capacities. It would be more efficient, therefore, to first stock batches optimally before using genetically improved fish to increase farm profit. We verified the outcome of this hypothesis of suboptimal constant stocking - i.e. stocking fish in all batches at a level such that the most critical batch would not reach the oxygen limitation at any time - using our bioeconomic model (data not shown). This resulted in lower gains due to lower overall stocking rate, but a similar pattern with EVs of TGC at low temperatures being zero or negative and higher at high temperatures. Furthermore, Hernández et al. (2007) as well as Seginer and Ben-Asher (2011) showed that optimal harvest weight also changes according to temperature. However, in our study we considered fixed harvest weight as a market requirement; the effect of genetic improvement of TGC on optimal harvest weight would require further investigation.

Another main assumption of the model is the independence of feed conversion ratio (FCR) relative to TGC. Ponzoni et al. (2007) showed that the economic return of implementing 
genetic improvement of harvest weight would increase the benefit/cost ratio of a farm producing tilapia in Malaysia if the genetic correlation of harvest weight with feed intake was 0.85, which implies a correlated response in FCR to selection on harvest weight. When including a correlated response between TGC and FCR, the EV of TGC would be partly influenced by the better efficiency of the fish. However, there is not yet consensus on the genetic correlation between TGC and FCR because FCR is a trait difficult to measure on individual fish (Thodesen et al., 1999; Sanchez et al., 2001; Mambrini et al., 2004; Silverstein et al., 2005; Kause et al., 2006). Moreover, we wanted to focus this paper on studying the effect of growth per se (and not an hypothetical correlated increase in feed efficiency) in an environment with limited supply of oxygen. For these reasons, we chose to implement an empirical equation of FCR dependent on fish weight (Lanari et al., 2002) and temperature (Person-Le Ruyet et al., 2004) rather than a bioenergetics model. A bioenergetics model such as presented by Cho and Bureau (1998) would generate an intrinsic correlation between TGC and FCR whereas with Eq. [7], daily FCR depends only on body weight and temperature. Whatever the TGC value, the individual FCR integrated over the growing period remained constant to 2.0 using Eq. [7].

Considering these main assumptions, our results show that implementing genetic selection to improve only TGC would not be economically profitable for all fish farms across the Mediterranean. Given the climatic conditions, the western and eastern part of the Mediterranean could require a separate breeding program. This is comparable to the conclusion of Rose et al. (2015) who demonstrated that sheep breeding programs in Australia should be region specific, depending on pasture growth. For sea bass in Europe, most breeding programs include several traits in the breeding objective (Chavanne et al., 2016; Janssen et al., In Press). Therefore, to confirm the hypothesis that different breeding programs between eastern and western Mediterranean are needed, the economic values of all the traits 
in the breeding objectives and the correlation between breeding objectives from both regions should be estimated (Rose et al., 2015).

When multiple traits are included in a breeding objective the response to selection is the response in the aggregate genotype. The aggregate genotype is calculated by the sum of the products of the economic value of all traits and the responses per trait. The responses per trait depend on the additive genetic variance of each trait, but also on genetic correlations between traits in the aggregate genotype. TGC is a trait with high heritability and easy to measure. Despite the fact that it has a negative economic value in certain regions it could still be interesting to select fish with faster growth because of positive genetic correlations with other economically interesting traits. For instance, fillet yield is an economic important trait in fish farming and Rutten et al. (2005) showed that the genetic correlation between body weight and fillet yield in Nile tilapia (Oreochromis niloticus) was 0.74 . Therefore, improvement of fillet yield could be obtained through selection for increased body weight. FCR is another important trait that could simultaneously increase economic return and decrease environmental impacts (Besson et al., 2014). However, further research is needed to quantify the genetic correlation of feed conversion ratio with growth traits.

Finally, our results raise the idea of evaluating the potential for selecting traits related to oxygen consumption and to estimate the genetic correlation of these traits with TGC. Previous studies already suggested a high heritability about 0.5 for tolerance to hypoxia in common carp (Nagy et al., 1980). Our bioeconomic model could be extended in future work to compute the economic interest of changing the tolerance to hypoxia for sea bass. Positive economic values would makes tolerance to hypoxia a potential interesting trait to breed for, provided that the trait shows sufficient additive genetic variance. 


\section{Conclusion}

Our study is the first investigating the economic impact of genetic improvement of growth rate (TGC) in sea bass reared in sea cages with different temperature profiles. Oxygen supply was considered the limiting factor constraining stocking density in the cages. We show through the calculation of economic values that the economic impact is dependent on temperature conditions. When the average temperature was $18^{\circ} \mathrm{C}$, which corresponds to the average temperature encountered in the western Mediterranean, improving TGC did not impact farm profit. However, when the average temperature was $19.5{ }^{\circ} \mathrm{C}$ or $21{ }^{\circ} \mathrm{C}$ like in eastern Mediterranean, improving TGC had a positive impact on farm profit. These results emphasize the need of calculating economic values of all the traits included in breeding programs of sea bass to investigate the potential need of developing different breeding objectives according to the geographic location.

\section{Acknowledgement}

M. Besson benefited from a joint grant from the European Commission and IMARES, within the framework of the Erasmus-Mundus joint doctorate "EGS-ABG". The authors thank Kefalonia Fisheries and Gloria Maris for their collaboration. M. Besson is grateful to K. Janssen for his help in developing the bioeconomic model. 


\section{References}

Amer, P. R., Fox, G. C., Smith, C., 1994. Economic weights from profit equations: appraising their accuracy in the long run. Anim. Sci. 58, 11-18

Bahri-Sfar, L., Lemaire, C., Hassine, O. K. B., Bonhomme, F., 2000. Fragmentation of sea bass populations in the western and eastern Mediterranean as revealed by microsatellite polymorphism. P. Roy. Soc. Lond. B. Bio. 267, 929-935.

Besson, M., Komen, H., Aubin, J., de Boer, I.J.M., Poelman, M., Quillet, E., Vancoilie, C., Vandeputte, M., van Arendonk, J.A.M., 2014. Economic values of growth and feed efficiency for fish farming in recirculating aquaculture system with density and nitrogen output limitations: a case study with African catfish (Clarias gariepinus). J. Anim. Sci. 92, 5394-5405.

Brafield, A. E., Llewellyn, M. J., 1982. Animal energetics. Blackie Glasgow, UK.

Brafield, A. E., Solomon, D. J., 1972. Oxy-calorific coefficients for animals respiring nitrogenous substrates. Comparative Biochemistry and Physiology Part A: Physiology 43, 837-841.

Breitburg, D., 2002. Effects of hypoxia, and the balance between hypoxia and enrichment, on coastal fishes and fisheries. Estuaries 25, 767-781.

Chavanne, H., Janssen, K., Hofherr, J., Contini, F., Haffray, P., Komen, H., Nielsen, E. E., Bargelloni, L., 2016. A comprehensive survey on selective breeding programs and seed market in the European aquaculture fish industry. Aquat. Int. 1-21.

Cho, C. Y., 1990. Feeding systems for rainbow trout and other salmonids with reference to current estimates of energy and protein requirements. Aquaculture 100, 107-123.

Cho, C. Y., Bureau, D. P., 1998. Development of bioenergetic models and the Fish-PrFEQ software to estimate production, feeding ration and waste output in aquaculture. Aquat. Living. Resour. 11, 199-210.

Cho, C. Y., Kaushik, S. J., 1990. Nutritional energetics in fish: energy and protein utilization in rainbow trout (Salmo gairdneri). World. Rev. Nutr. Diet. 72, 61-132.

Conover, D. O., Brown, J. J., Ehtisham, A., 1997. Countergradient variation in growth of young striped bass (Morone saxatilis) from different latitudes 1. Can. J. Fish. Aquat. Sci. 54, 2401-2409.

Coves, D., Dewavrin, G., Breuil, G., Devauchelle, N., 1991. Culture of sea bass (Dicentrarchus labrax L.).

Dekkers, J. C. M., 1991. Estimation of economic values for dairy cattle breeding goals: Bias due to sub-optimal management policies. Livest. Prod. Sci. 29, 131-149.

Dupont-Nivet, M., Karahan-Nomm, B., Vergent, A., Merdy, O., Haffray, P., Chavanne, H., Chatain, B., Vandeputte, M., 2010. Genotype by environment interactions for growth in European seabass (Dicentrarchus labrax) are large when growth rate rather than weight is considered. Aquaculture 306, 365-368.

Elliott, J., Davison, W., 1975. Energy equivalents of oxygen consumption in animal energetics. Oecologia 19, 195-201.

Gasca-Leyva, E., León, C. J., M. Hernández, J., Vergara, J. M., 2002. Bioeconomic analysis of production location of sea bream (Sparus aurata) cultivation. Aquaculture 213, 219-232.

Groen, A. 1989. Economic values in cattle breeding. II. Influences of production circumstances in situations with output limitations. Livest. Prod. Sci. 22, 17-30.

Hernández, J. M., León-Santana, M., León, C. J., 2007. The role of the water temperature in the optimal management of marine aquaculture. Eur. J. Oper. Res. 181, 872-886. 
Imsland, A., Jonassen, T., 2001. Regulation of growth in turbot (Scophthalmus maximus Rafinesque) and Atlantic halibut (Hippoglossus hippoglossus L.): aspects of environment $\times$ genotype interactions. Rev. Fish. Biol. Fisher. 11, 71-90.

Janssen, K., Chavanne, H., Berentsen, P., Komen., H., 2016. Impact of selective breeding on European aquaculture. Aquaculture doi:10.1016/j.aquaculture.2016.03.012

Kause, A., Tobin, D., Houlihans, D.F., Martin, S.A.M., Mäntusaari, E.A., Ritola, O., Ruohonen, K., 2006. Feed efficiency of rainbow trout can be improved through selection: Different genetic potential on alternative diets. J. Anim. Sci. 84, 807-817.

Kaushik, S, J., 1998. Nutritional bioenergetics and estimation of waste production in nonsalmonids. Aquat. Living. Resour. 11(4), 211-217.

Kaushik, S. J., Covès, D., Dutto, G., Blanc, D., 2004. Almost total replacement of fish meal by plant protein sources in the diet of a marine teleost, the European seabass, Dicentrarchus labrax. Aquaculture 230, 391-404.

Lanari, D., D’Agaro, E. , Ballestrazzi, R., 2002. Growth parameters in European sea bass (Dicentrarchus labrax L.): effects of live weight and water temperature. Ital. J. Anim. Sci. 1, 181-186.

Llorente, I., Luna, L., 2013. The competitive advantages arising from different environmental conditions in seabream, Sparus aurata, production in the Mediterranean Sea. J. World. Aquacult. Soc. 44,611-627.

Mallet, J. P., Charles, S., Persat, H., Auger, P., 1999. Growth modelling in accordance with daily water temperature in European grayling (Thymallus thymallus L.). Can. J. Fish. Aquat. Sci. 56, 994-1000.

Mambrini, M., Médale, F., Sanchez, M.P., Recalde, B., Chevassus, B., Labbé, L., Quillet, E., Boujard, T., 2004. Selection for growth in brown trout increases feed intake capacity without affecting maintenance and growth requirements. J. Anim. Sci. 82, 2865-2875.

Naciri, M., Lemaire, C., Borsa, P., Bonhomme, F., 1999. Genetic study of the Atlantic/Mediterranean transition in sea bass (Dicentrarchus labrax). J. Hered. 90, 591-596.

Nagy, A., Csanyi, V., Bakos, J., Horvath, L., 1980. Development of a short-term laboratory system for the evaluation of carp growth in ponds. Bamidgeh 32. 6-15.

Person-Le Ruyet, J., Mahé, K., Le Bayon, N., Le Delliou, H., 2004. Effects of temperature on growth and metabolism in a Mediterranean population of European sea bass, Dicentrarchus labrax. Aquaculture 237, 269-280.

Pichavant, K., Person-Le Ruyet, J., Le Bayon, N., Severe, A., Le Roux, A., Boeuf, G., 2001. Comparative effects of long-term hypoxia on growth, feeding and oxygen consumption in juvenile turbot and European sea bass. J. Fish. Biol. 59, 875-883.

Ponzoni, R.W., Nguyen, N.H., Khaw, H.L., 2007. Investment appraisal of genetic improvement programs in Nile tilapia (Oreochromis niloticus). Aquaculture 269, 187199.

R Development Core Team, 2008. R: A language and environment for statistical computing. R Foundation for Statistical Computing, Vienna, Austria.

Rose, G., Mulder, H. A., Thompson, A. N., van der Werf, J. H. J., van Arendonk, J. A. M., 2015. Breeding objectives for sheep should be customised depending on variation in pasture growth across years. Animal 9:8, 1-10.

Rutten, M. J. M., Bovenhuis, H., Komen, H., 2005. Genetic parameters for fillet traits and body measurements in Nile tilapia (Oreochromis niloticus L.). Aquaculture 246, 125132.

Sae-Lim, P., Komen, H., Kause, A., van Arendonk, J.A.M., Barfoot, A.J., Martin, K.E., Parsons J.E., 2012. Defining desired genetic gains for rainbow trout breeding objective using analytic hierarchy process. J. Anim. Sci. 90. 1766-1776. 
Sanchez, M.-P., Chevassus, B., Labbé, L., Quillet, E., Mambrini, M., 2001. Selection for growth of brown trout (Salmo trutta) affects feed intake but not feed efficiency. Aquat. Living. Resour. 14, 41-48.

Seginer, I., Ben-Asher, R., 2011. Optimal harvest size in aquaculture, with RAS cultured sea bream (Sparus aurata) as an example. Aquacult. Eng. 44, 55-64.

Seginer, I., Halachmi, I., 2008. Optimal stocking in intensive aquaculture under sinusoidal temperature, price and marketing conditions. Aquacult. Eng. 39, 103-112.

Silverstein, J. T., Hostuttler, M., Blemings, K. P., 2005. Strain differences in feed efficiency measured as residual feed intake in individually reared rainbow trout, Oncorhynchus mykiss (Walbaum). Aquac. Res. 36, 704-711.

Thetmeyer, H., Waller, U., Black, K. D., Inselmann, S., Rosenthal, H., 1999. Growth of European sea bass (Dicentrarchus labrax L.) under hypoxic and oscillating oxygen conditions. Aquaculture 174, 355-367.

Thodesen, J., Grisdale-Helland, B., Helland, S. J., Gjerde, B., 1999. Feed intake, growth and feed utilization of offspring from wild and selected Atlantic salmon (Salmo salar). Aquaculture 180, 237-246.

Vandeputte, M., Garouste, R., Dupont-Nivet, M., Haffay, P., Vergnet, A., Chavanne, H., Laureau, S., Ron, T.B., Pagelson, G., Mazorra, C., Ricoux, R., Marques, P., Gameiro, Marta., Chatain, B., 2014. Multi-site evaluation of the rearing performances of 5 wild populations of European sea bass (Dicentrarchus labrax). Aquaculture 424-425, 239248.

Villanueva, R. R., Araneda, M. E., Vela, M., Seijo, J. C., 2013. Selecting stocking density in different climatic seasons: A decision theory approach to intensive aquaculture. Aquaculture 384-387, 25-34.

Weiss, R. F., 1970. The solubility of nitrogen, oxygen and argon in water and seawater. Deep. Sea. Res. 17, 721-735. 


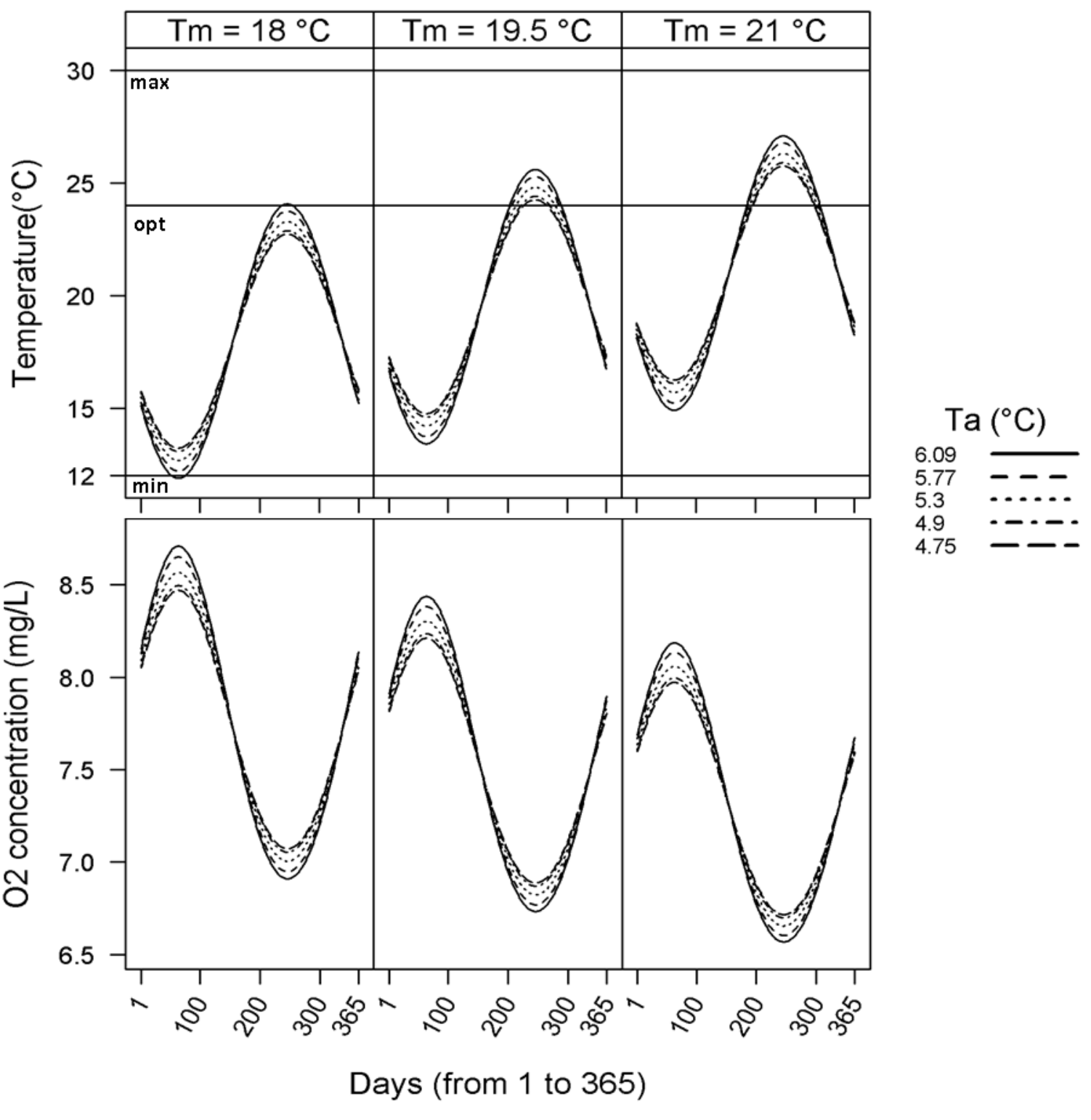

Figure 1

Graphical presentation of the temperature conditions tested and the resulting oxygen concentration in sea water. Tm is the average temperature and $\mathrm{Ta}$ is the amplitude of the temperature. max, opt and min are respectively the maximum, optimum and minimum temperature for sea bass rearing. 


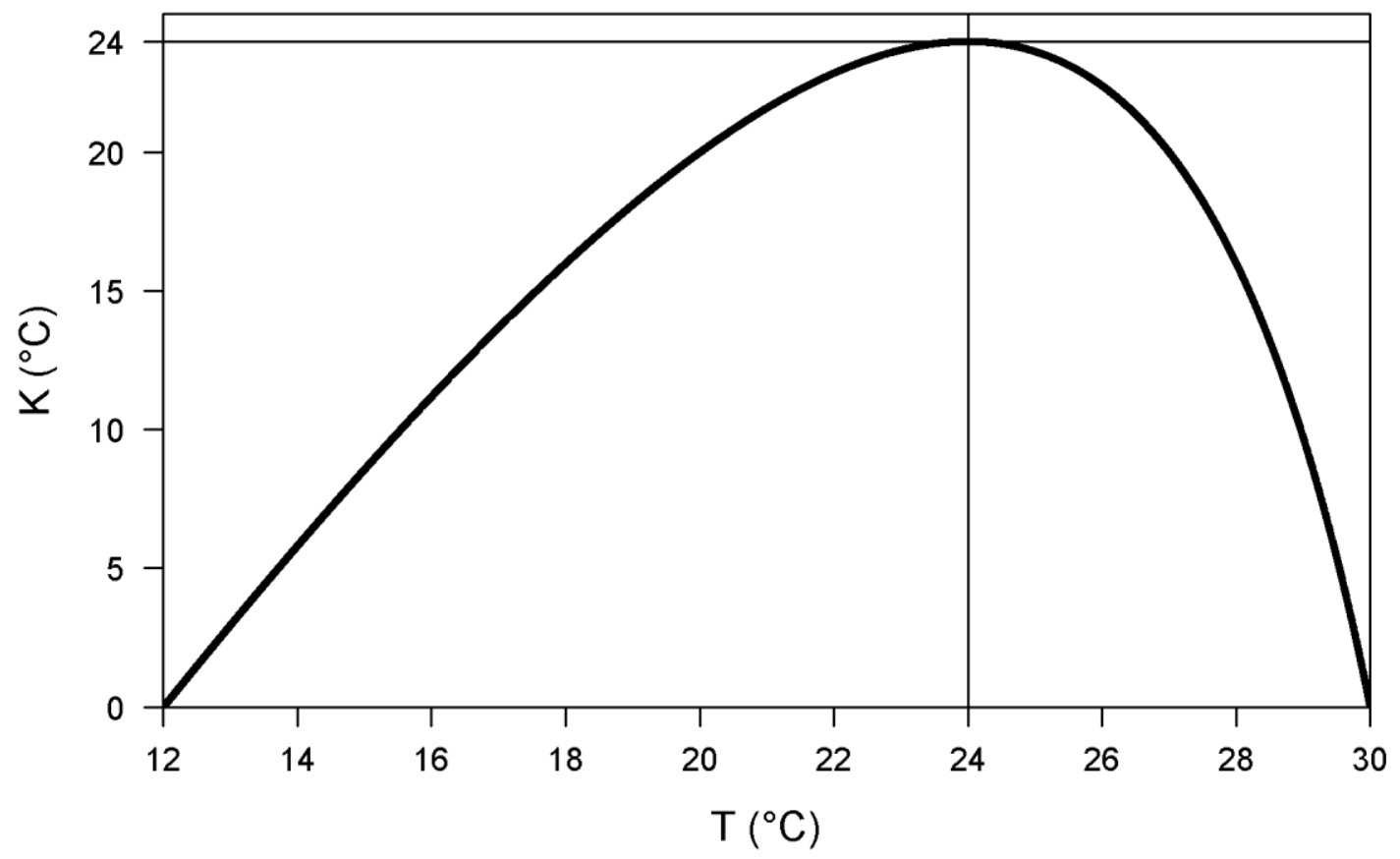

Figure 2

Temperature $\mathrm{K}$ as a function of temperature $\mathrm{T}$. $\mathrm{K}$ reaches a maximum at $24{ }^{\circ} \mathrm{C}$ when temperature $\mathrm{T}$ is $24^{\circ} \mathrm{C}$. 


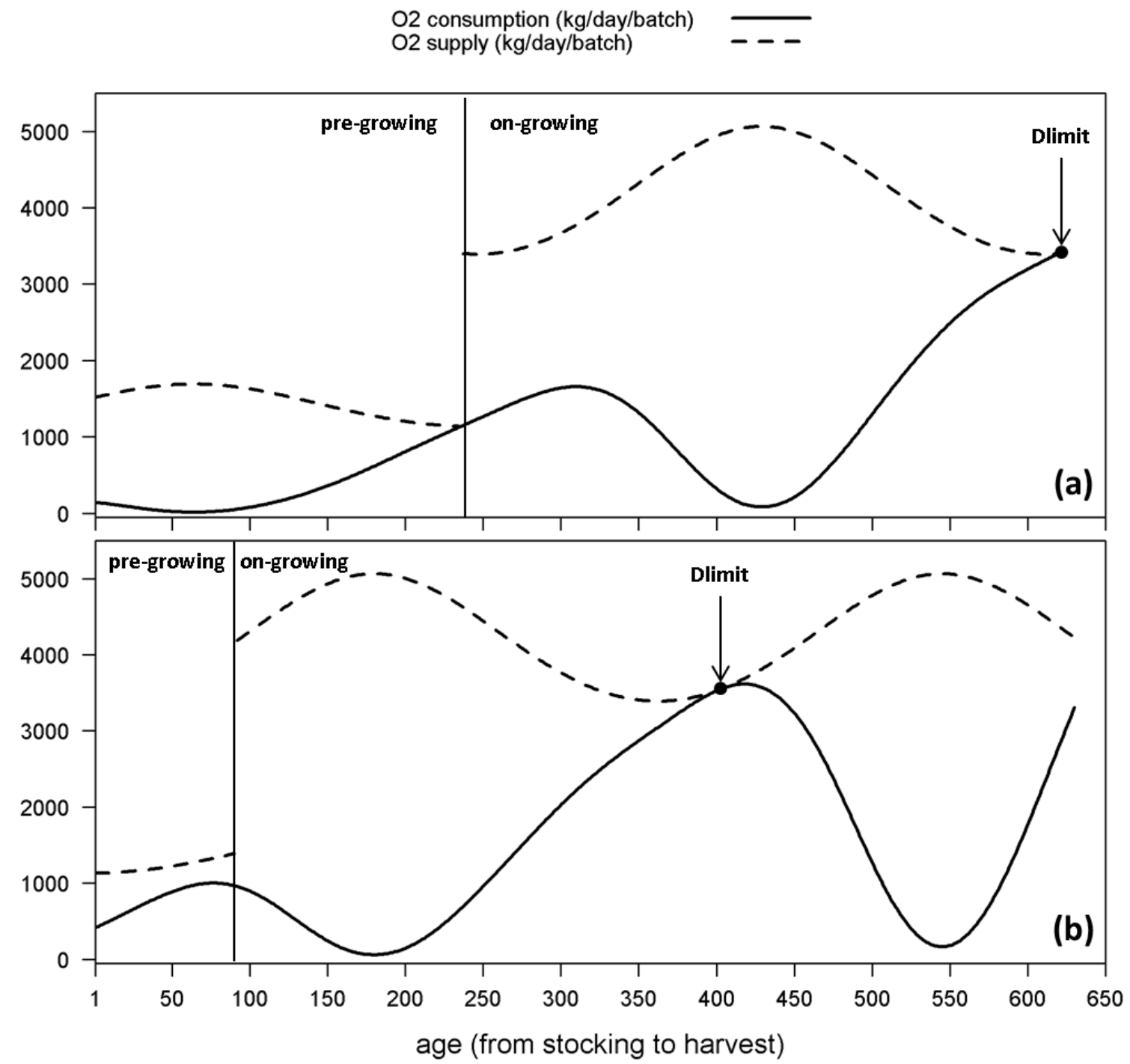

Figure 3

Total daily oxygen consumption (full line) of a batch stocked on the $1^{\text {st }}$ of January (a) and on the $7^{\text {th }}$ of September (b) from harvest to stocking compared to the total daily oxygen supply of this batch (dash line) during pre-growing $\left(600 \mathrm{~m}^{3}\right.$ cages) and on-growing (1800 $\mathrm{m}^{3}$ cages). The point represents the day when the oxygen consumption of the batch is equal to the oxygen supply (Dlimit). When the batch is stocked on the $1^{\text {st }}$ of January, Dlimit is reached at harvest and the number of fish stocked is 82,512 . When the batch is stocked on the $7^{\text {th }}$ of September, Dlimit is reached during on-growing period and the number of fish socked is 117,557. 

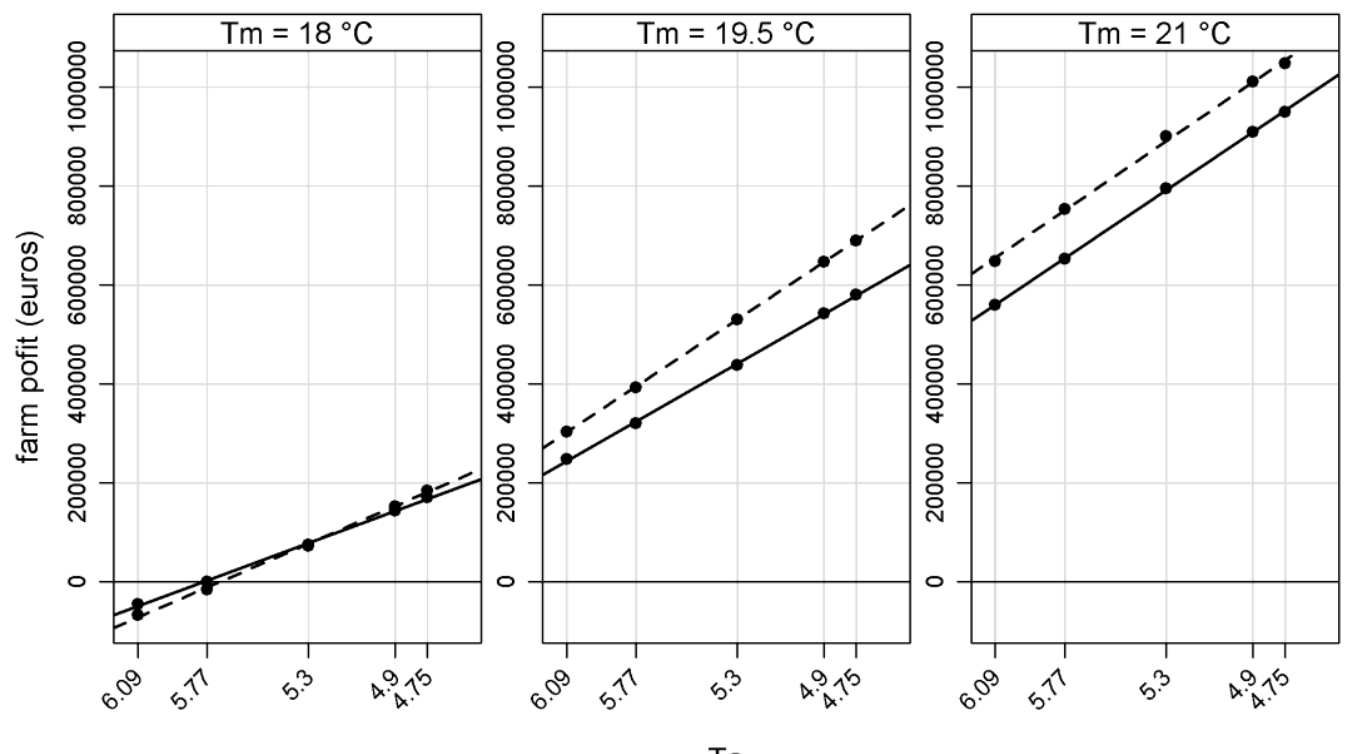

TGC

$2.25---$

Ta

\section{Figure 4}

Annual profit per farm for different thermal growth coefficient (TGC) and as a function of the average (Tm) and the amplitude (Ta) of temperature. 


\section{Table 1}

Summary of the different average temperature (Tm) and variation (Ta) tested.

\begin{tabular}{|c|c|c|c|c|}
\hline & & & & \\
\hline & & 18 & 19.5 & 21 \\
\hline \multirow{5}{*}{$\mathrm{Ta}\left(\right.$ in $\left.{ }^{\circ} \mathrm{C}\right)$} & 6.09 & $\overline{\mathrm{ES}^{2}}$ & & \multirow{5}{*}{$\mathrm{ST}^{2}$} \\
\hline & 5.77 & $\mathrm{SF}^{1}$ & & \\
\hline & 5.3 & & & \\
\hline & 4.9 & & $\mathrm{WG}^{2}$ & \\
\hline & 4.75 & $\mathrm{NWI}^{2}$ & $\mathrm{SG}^{2}$ & \\
\hline
\end{tabular}

The letters indicates the region of the Mediterranean sea corresponding to these temperature parameters, $1=$ personal data, $2=$ Llorente and Luna (2013). $\mathrm{SF}=$ southern France $(\mathrm{Tm}=18, \mathrm{Ta}=5.77), \mathrm{ES}=$ eastern Spain $(\mathrm{Tm}=18, \mathrm{Ta}=6.09), \mathrm{WG}=$ western Greece $(\mathrm{Tm}=19.25, \mathrm{Ta}=5.0), \mathrm{SG}=$ south Greece $(\mathrm{Tm}=$ 19.34, $\mathrm{Ta}=4.75), \mathrm{NWI}=$ northwestern Italy $(\mathrm{Tm}=18, \mathrm{Ta}=4.72)$ and $\mathrm{ST}=$ southern Turkey $(\mathrm{Tm}=20.84$, $\mathrm{Ta}=5.3)$ 
Table 2

Data used in equation of oxygen consumption.

\begin{tabular}{lccc}
\hline & protein & fat & carbohydrate \\
& & & \\
\hline Feed content $(\mathrm{g} / \mathrm{g})$ & $0.46^{1}$ & $0.14^{1}$ & $0.21^{1}$ \\
Fish content $(\mathrm{g} / \mathrm{g})$ & $0.16^{2}$ & $0.19^{2}$ & - \\
Digestibility $(\mathrm{g} / \mathrm{g})$ & $0.94^{2}$ & $0.9^{2}$ & $0.7^{2}$ \\
Oxy-caloric coefficient $\left(\mathrm{kJ} / \mathrm{g} \mathrm{O}_{2}\right)$ & $14.8^{3}$ & $13.7^{4}$ & $13.4^{3}$ \\
Energy content $(\mathrm{kJ} / \mathrm{g})$ & $17.2^{5}$ & $39.5^{5}$ & $23.6^{5}$ \\
& & & \\
\hline
\end{tabular}

${ }^{1}$ Biomar EFICO YM 868

${ }^{2}$ (Kaushik et al., 2004)

${ }^{3}$ (Brafield and Solomon, 1972)

${ }^{4}$ (Elliott and Davison, 1975)

5 (Brafield and Llewellyn, 1982) 
Table 3

Revenue and costs (variable and fixed) of a sea bass farm in the reference scenario.

\begin{tabular}{lccc}
\hline item & abbreviation & value & unit \\
\hline Price of fish & Pfish & 5.57 & $€ / \mathrm{kg}$ \\
Cost of feed & Cfeed & 1.3 & $€ / \mathrm{kg}$ \\
Cost of juveniles & Cjuv & 0.25 & $€ / \mathrm{pc}$ \\
\hline Fixed costs & Cfixed & $2,245,000$ & $€ /$ farm \\
\hline
\end{tabular}




\section{Table 4}

Summary of some important parameters of the bioeconomic model with their abbreviation and unit.

\begin{tabular}{|c|c|c|}
\hline Parameters & Abbreviations & Units \\
\hline Daily temperature & $\mathrm{T}_{\mathrm{n}}$ & ${ }^{\circ} \mathrm{C}$ \\
\hline Daily corrected temperature & $\mathrm{K}_{\mathrm{n}}$ & ${ }^{\circ} \mathrm{C}$ \\
\hline Daily oxygen concentration & {$[\mathrm{O} 2]_{\mathrm{n}}$} & $\mathrm{mg} / \mathrm{L}$ \\
\hline Thermal growth coefficient & TGC & - \\
\hline Daily weight & $\mathrm{W}_{\mathrm{n}}$ & g \\
\hline Daily weight gain & $\mathrm{DWG}_{\mathrm{n}}$ & g/day \\
\hline Feed conversion ratio & $\mathrm{FCR}_{W n}$ & $g / g$ \\
\hline Daily feed intake & $D F I_{n}$ & g/day \\
\hline Daily oxygen consumption of fish & O2_cons_fish $n$ & $\mathrm{mg} /$ fish/day \\
\hline Cumulative mortality & M & $\%$ \\
\hline Daily oxygen cage supply & & $\mathrm{mg} /$ cage/day \\
\hline Number of fish stock per cage & Nb_fish_stocked ${ }_{n}$ & $\# /$ cage \\
\hline Fish production of batch & Prod_fish ${ }_{\text {batch }}$ & g/cage \\
\hline Fish production of farm & Prod_fish ${ }_{\text {farm }}$ & $\mathrm{g} /$ farm \\
\hline Number of batch produced per year & $\mathrm{Nb} \_$batch ${ }_{\text {year }}$ & \#/year/farm \\
\hline Farm profit & Profit $_{\text {farm }}$ & $€ /$ year/farm \\
\hline
\end{tabular}


Table 5

Effect of different values of thermal growth coefficient (TGC) on fish production parameters according to the average (Tm) and the amplitude (Ta) of temperature.

\begin{tabular}{cccccccc}
\hline $\begin{array}{c}\text { Tm } \\
\left({ }^{\circ} \mathrm{C}\right)\end{array}$ & $\begin{array}{c}\text { Ta } \\
\left({ }^{\circ} \mathrm{C}\right)\end{array}$ & TGC & $\begin{array}{c}\text { Time to } \\
\text { harvest } \\
\text { (days) }\end{array}$ & $\begin{array}{c}\text { Number of } \\
\text { fish stocked } \\
\text { per batch }\end{array}$ & $\begin{array}{c}\text { Number } \\
\text { of batch } \\
\text { produced } \\
\text { per year }\end{array}$ & $\begin{array}{c}\text { Production } \\
\text { at farm } \\
\text { level } \\
\text { (tonnes) }\end{array}$ & $\begin{array}{c}\text { Feed } \\
\text { consumption } \\
\text { at farm } \\
\text { (tonnes) }\end{array}$ \\
\hline 18 & 6.09 & 2.25 & 580 & 89,598 & 30.27 & 976 & 1,975 \\
18 & 6.09 & 2.38 & 554 & 84,475 & 31.85 & 969 & 1,962 \\
18 & 5.77 & 2.25 & 573 & 91,023 & 30.54 & 1,001 & 2,032 \\
18 & 5.77 & 2.38 & 547 & 86,047 & 32.15 & 996 & 2,026 \\
18 & 5.3 & 2.25 & 564 & 93,596 & 30.89 & 1,041 & 2,125 \\
18 & 5.3 & 2.38 & 537 & 88,865 & 32.57 & 1,042 & 2,131 \\
18 & 4.9 & 2.25 & 556 & 96,203 & 31.11 & 1,078 & 2,210 \\
18 & 4.9 & 2.38 & 530 & 91,648 & 32.85 & 1,084 & 2,227 \\
\hline 18 & 4.75 & 2.25 & 554 & 97,275 & 31.18 & 1,092 & 2,243 \\
18 & 4.75 & 2.38 & 527 & 92,791 & 32.94 & 1,100 & 2,265 \\
\hline 19.5 & 6.09 & 2.25 & 504 & 88,754 & 34.82 & 1,113 & 2,261 \\
19.5 & 6.09 & 2.38 & 479 & 85,653 & 36.96 & 1,140 & 2,320 \\
19.5 & 5.77 & 2.25 & 496 & 90,250 & 35.30 & 1,147 & 2,334 \\
19.5 & 5.77 & 2.38 & 471 & 87,585 & 37.46 & 1,181 & 2,407 \\
19.5 & 5.3 & 2.25 & 485 & 92,929 & 35.91 & 1,201 & 2,448 \\
19.5 & 5.3 & 2.38 & 460 & 90,642 & 38.13 & 1,244 & 2,539 \\
19.5 & 4.9 & 2.25 & 476 & 95,483 & 36.34 & 1,249 & 2,548 \\
19.5 & 4.9 & 2.38 & 452 & 93,305 & 38.65 & 1,298 & 2,652 \\
\hline 19.5 & 4.75 & 2.25 & 474 & 96,456 & 36.49 & 1,267 & 2,586 \\
19.5 & 4.75 & 2.38 & 449 & 94,267 & 38.83 & 1,318 & 2,693 \\
\hline 21 & 6.09 & 2.25 & 460 & 91,102 & 38.19 & 1,252 & 2,547 \\
21 & 6.09 & 2.38 & 436 & 88,681 & 40.54 & 1,294 & 2,635 \\
\hline 21 & 5.77 & 2.25 & 450 & 92,306 & 38.90 & 1,293 & 2,626 \\
21 & 5.77 & 2.38 & 426 & 89,835 & 41.39 & 1,339 & 2,722 \\
\hline 21 & 5.3 & 2.25 & 437 & 94,084 & 39.92 & 1,352 & 2,740 \\
21 & 5.3 & 2.38 & 413 & 91,149 & 42.65 & 1,399 & 2,837 \\
\hline 21 & 4.9 & 2.25 & 427 & 95,420 & 40.74 & 1,400 & 2,830 \\
21 & 4.9 & 2.38 & 403 & 91,952 & 43.62 & 1,444 & 2,919 \\
\hline 21 & 4.75 & 2.25 & 424 & 95,863 & 41.03 & 1,416 & 2,861 \\
21 & 4.75 & 2.38 & 400 & 92,220 & 43.95 & 1,459 & 2,948 \\
\hline & & & & & & & \\
\hline
\end{tabular}




\section{Table 6}

Effect of different values of thermal growth coefficient (TGC) on economic parameters according to the average (Tm) and the amplitude (Ta) of temperature.

\begin{tabular}{cccccccc}
\hline $\begin{array}{c}\text { Tm } \\
\left({ }^{\circ} \mathrm{C}\right)\end{array}$ & $\begin{array}{c}\text { Ta } \\
\left({ }^{\circ} \mathrm{C}\right)\end{array}$ & TGC & $\begin{array}{c}\text { Income } \\
(€ \times 1000)\end{array}$ & $\begin{array}{c}\text { Feed cost } \\
(€ \times 1000)\end{array}$ & $\begin{array}{c}\text { Juveniles } \\
\text { cost } \\
(€ \times 1000)\end{array}$ & $\begin{array}{c}\text { Cost per } \\
\text { kg of fish } \\
(€ / \mathrm{kg})\end{array}$ & $\begin{array}{c}\text { Profit } \\
(€ / \text { farm })\end{array}$ \\
\hline 18 & 6.09 & 2.25 & 5,446 & 2,568 & 678 & 5.62 & $-45,214$ \\
18 & 6.09 & 2.38 & 5,402 & 2,551 & 673 & 5.65 & $-66,784$ \\
18 & 5.77 & 2.25 & 5,582 & 2,642 & 695 & 5.58 & 0 \\
18 & 5.77 & 2.38 & 5,555 & 2,633 & 692 & 5.59 & $-15,449$ \\
18 & 5.3 & 2.25 & 5,805 & 2,762 & 723 & 5.51 & 74,554 \\
18 & 5.3 & 2.38 & 5,811 & 2,770 & 723 & 5.51 & 72,147 \\
18 & 4.9 & 2.25 & 6,010 & 2,873 & 748 & 5.44 & 143,775 \\
18 & 4.9 & 2.38 & 6,045 & 2,895 & 753 & 5.44 & 152,557 \\
18 & 4.75 & 2.25 & 6,089 & 2,915 & 758 & 5.42 & 170,527 \\
18 & 4.75 & 2.38 & 6,138 & 2,944 & 764 & 5.41 & 184,506 \\
\hline 19.5 & 6.09 & 2.25 & 6,205 & 2,940 & 773 & 5.35 & 247,682 \\
19.5 & 6.09 & 2.38 & 6,356 & 3,016 & 791 & 5.31 & 303,736 \\
19.5 & 5.77 & 2.25 & 6,396 & 3,034 & 796 & 5.30 & 320,726 \\
19.5 & 5.77 & 2.38 & 6,587 & 3,129 & 820 & 5.24 & 392,728 \\
\hline 19.5 & 5.3 & 2.25 & 6,700 & 3,182 & 834 & 5.21 & 438,219 \\
19.5 & 5.3 & 2.38 & 6,940 & 3,301 & 864 & 5.15 & 529,892 \\
19.5 & 4.9 & 2.25 & 6,968 & 3,313 & 868 & 5.14 & 542,143 \\
19.5 & 4.9 & 2.38 & 7,241 & 3,447 & 902 & 5.08 & 646,883 \\
\hline 19.5 & 4.75 & 2.25 & 7,067 & 3,362 & 880 & 5.12 & 580,097 \\
19.5 & 4.75 & 2.38 & 7,350 & 3,500 & 915 & 5.05 & 689,614 \\
\hline 21 & 6.09 & 2.25 & 6,985 & 3,312 & 870 & 5.13 & 558,925 \\
21 & 6.09 & 2.38 & 7,217 & 3,426 & 899 & 5.08 & 648,228 \\
21 & 5.77 & 2.25 & 7,209 & 3,414 & 898 & 5.07 & 653,052 \\
21 & 5.77 & 2.38 & 7,466 & 3,538 & 930 & 5.01 & 753,179 \\
21 & 5.3 & 2.25 & 7,541 & 3,562 & 939 & 4.99 & 795,111 \\
21 & 5.3 & 2.38 & 7,805 & 3,688 & 972 & 4.93 & 900,171 \\
21 & 4.9 & 2.25 & 7,806 & 3,679 & 972 & 4.93 & 909,191 \\
21 & 4.9 & 2.38 & 8,053 & 3,795 & 1,003 & 4.88 & $1,010,105$ \\
21 & 4.75 & 2.25 & 7,897 & 3719 & 983 & 4.91 & 949,081 \\
21 & 4.75 & 2.38 & 8,138 & 3,832 & 1,013 & 4.86 & $1,047,939$ \\
\hline & & & & & & &
\end{tabular}


Table 7

Economic values (in $€ / \mathrm{kg}$ ) of thermal growth coefficient (TGC) according to the average (Tm) and the amplitude (Ta) of temperature. When $\sigma_{\mathrm{g}}=0.13$.

\begin{tabular}{|c|c|c|c|c|}
\hline & & \multicolumn{2}{|c|}{$\operatorname{Tm}\left({ }^{\circ} \mathrm{C}\right)$} & \multirow[b]{2}{*}{21} \\
\hline & & 18 & 19.5 & \\
\hline \multirow{5}{*}{$\mathrm{Ta}\left({ }^{\circ} \mathrm{C}\right)$} & 6.09 & -0.02 & 0.05 & 0.07 \\
\hline & 5.77 & -0.02 & 00 & 0.08 \\
\hline & 5.3 & 0 & 0.08 & 0.08 \\
\hline & 4.9 & 0.01 & 0.08 & 0.07 \\
\hline & 4.75 & 0.01 & 0.09 & 0.07 \\
\hline
\end{tabular}

